\title{
The Effect of Sea Lettuce (Ulva lactuca) Liquid Fertilizer and Zeolite Combinations on the Development of Cucumber (Cucumis sativus)
}

\author{
Mustafa Türkmen ${ }^{1, a, *}$, Ayşe Su ${ }^{1, b}$ \\ ${ }^{I}$ Department of Biology, Faculty of Science \& Arts, Giresun University, 28000 Giresun, Turkey \\ *Corresponding author

\begin{tabular}{|c|c|}
\hline A R T I C L E I N F O & A B S T R A C T \\
\hline $\begin{array}{l}\text { Keywords: } \\
\text { Zeolite } \\
\text { Ulva lactuca } \\
\text { Cucumber } \\
\text { Liquid Fertilizer } \\
\text { Yield }\end{array}$ & $\begin{array}{l}\text { The combinations of organic liquid fertilizer material obtained from sea lettuce (Ulva lactuca) and } \\
\text { different concentrations of zeolite were applied to the cucumber (Cucumis sativus) plant in six } \\
\text { treatments with three replicates each. The combinations of the experimental groups were as follows; } \\
\text { control group, G1 group } 180 \mathrm{~g} \mathrm{Z} \text { (Zeolite), G2 group } 90 \mathrm{~g} \mathrm{Z}+1140 \mathrm{ml} \text { Liquid Fertilizer (LF), G3 } \\
\text { group } 180 \mathrm{~g} \mathrm{Z}+620 \mathrm{ml} \mathrm{LF}, \mathrm{G} 4 \text { group } 270 \mathrm{~g} \mathrm{Z}+310 \mathrm{ml} \mathrm{LF}, \mathrm{G} 5 \text { group } 620 \mathrm{ml} \text { LF. Except the control } \\
\text { group, all zeolites were applied with the first dose of liquid fertilizer, and other liquid fertilizer doses } \\
\text { were given in three periods, after germination, flowering and yield. While the lowest germination } \\
\text { rate was in control group, the highest rate was in group with } 60 \mathrm{~g} \text { zeolite. While the lowest seedling } \\
\text { weight was observed in group with } 90 \mathrm{~g} \text { zeolite }+1140 \mathrm{ml} \text { liquid fertilizer, the highest rate was in } \\
\text { group with } 180 \mathrm{~g} \text { zeolite }+620 \mathrm{ml} \text { liquid fertilizer. While the highest cucumber weight was observed } \\
\text { in group with } 270 \mathrm{~g} \text { zeolite }+310 \mathrm{ml} \text { liquid fertilizer, the lowest was in group with } 620 \mathrm{ml} \text { liquid } \\
\text { fertilizer. Therefore, it may be said that zeolite has positive effect on germination. On the other hand, } \\
\text { liquid fertilizer and zeolite combinations may have positive effects on the weight of the cucumber } \\
\text { seedling and yield. }\end{array}$ \\
\hline
\end{tabular} \\ Yield
}

\section{Introduction}

The algae or seaweeds are a group of primitive organisms with no have true roots, stems and leaves. However, they are one of the import marine living resources with of enormous commercial importance. (Kaliaperumal et al., 1987). Seaweed products are best known for their auxin and cytokinin contents, as these endogenous phytohormones are liable for cell division and root and shoot elongation, respectively (Wickham and Davis, 2015). A sufficient level of potassium, nitrogen, growth promoting hormones, micronutrients, humic acids etc. present in seaweeds make it as excellent manure. Seaweed fertilizer besides increasing the soil fertility increases the moisture containment capacity and procures sufficient trace metals thereby improving the soil structure (Dhargalkar and Pereira, 2005). Liquid extract obtained from marine algae have been used over the past 40y on various plants to encourage growth and improving. Interest seaweed concentrates in agricultural system is focused on their use as an inexpensive source of naturally occurring plant growth regulator (Zodape, 2001). Seaweed liquid fertilizers are practical for obtaining higher agricultural production, because the extract contains growth encouraging hormones, IAA, IBA, Cytokinins, Gibberellins, trace elements, vitamins, amino acids, antibiotics and micronutrients (Raverkar, 2016). Utilized as foliar spray, soil conditioner and seed wet before sowing; these extracts give resistance to countless stresses such as frost, insect's infestation, viral and fungal diseases. Addition of seaweed-obtained liquid extracts increase soil quality and microbial activity (Rebours et al., 2014). Zeolite which is occurred of volcanic tuffs has been used to away the smell of natural manure and to enrich their content, and to increase the $\mathrm{pH}$ of the acidic soils for many years. Zeolite has been commonly used as transporter in fertilization and agricultural control (Gülen et al., 2012). Zeolite is a soil improver as it controls the moisture and $\mathrm{pH}$ content of soil. Therefore zeolite has been used traditionally by Japan farmers for centuries (Kurama et al., 1999) and broad usage of zeolite in aquaculture has been declared (Tepe et al., 2004). The main objective of the 
present study was to investigate the effects of different combinations of zeolite and the seaweed liquid fertilizer (SLF) obtained from Ulva lactuca on soil properties and the germination, seedling and eventually the yield of cucumber.

\section{Materials and Method}

Seaweed (Ulva lactuca) was collected with hand along the coastal waters of Giresun in May, 2015. Immediately on site, they were washed by seawater to clean the sediment, epiphytes and organic matter on their surface. The cleaned seaweed was transferred to laboratory in polythene bags and washed with tap water again in laboratory to remove the salt and pollution on the surface (Sivasankari et al., 2006). After then seaweed was dried in dark room for three days. Following the drying, it was cut into $0.5 \mathrm{~cm}$ to $1 \mathrm{~cm}$ in size and then $1 \mathrm{~kg}$ algae sample was boiled in 1 litter distilled water for an hour. It was allowed to cool at room temperature and was filtered. This seaweed extract was treated as $100 \%$ concentration and was diluted at a rate of 1:5 (Bhosle et al., 1975). In this study, some chemical features of the liquid fertilizer from Ulva lactuca were analysed in GRÜMLAB and obtained results are presented in Table 1.

The crop plant selected for the present study was Cucumis sativus belonging to the family Cucurbitaceae and purchased from a company that sells certified seeds. The soil used in the experiment was taken from the land belonging to Giresun Hazelnut Research Stations' surrounding gardens where the experiment was carried out. Zeolite used in the study was bought from Enli Mining Company. Chemical composition of the natural clinoptilolite used in the experiments were as follows; $\mathrm{SiO}_{2} ; 70.90, \mathrm{Al}_{2} \mathrm{O}_{3} ; 12.40, \mathrm{Fe}_{2} \mathrm{O}_{3} ; 1.21, \mathrm{~K}_{2} \mathrm{O} ; 4.46, \mathrm{CaO}$; 2.54, MgO; 0.83, $\mathrm{Na}_{2} \mathrm{O} ; 0.28, \mathrm{MnO} ;<0.01, \mathrm{TiO}_{2} ; 0.089$, $\mathrm{P}_{2} \mathrm{O}_{5} ; 0.02$ and water; 7.20 as percentage (Tepe et al., 2004). The six treatment groups with three replicates each were applied in randomized Complete Block Design between June and October 2015. The doses implemented in each the experimental groups are presented in Table 2.

Table 1 Some chemical features of the liquid fertilizer obtained from Ulva lactuca.

\begin{tabular}{l|r}
\multicolumn{1}{c|}{ Parameters } & Seaweed liquid fertilizer \\
\hline $\mathrm{N}(\%)$ & 0.16 \\
$\mathrm{C}(\%)$ & 1.24 \\
Total humic + fulvic acid (\%) & 25.50 \\
Soluble in water $\mathrm{K}_{2} \mathrm{O}(\%)$ & 0.14 \\
Total B (ppm) & 172.00 \\
$\mathrm{Cl}(\%)$ & 0.26 \\
$\mathrm{pH}$ & 8.00 \\
$\mathrm{P}(\mathrm{ppm})$ & 0.07 \\
$\mathrm{Se}(\mathrm{ppm})$ & 1.68 \\
$\mathrm{Mn}(\mathrm{ppm})$ & 2.20 \\
$\mathrm{Fe}(\mathrm{ppm})$ & 61.50 \\
$\mathrm{Co}(\mathrm{ppm})$ & 0.47 \\
$\mathrm{Ni}(\mathrm{ppm})$ & 0.14 \\
$\mathrm{Cu}(\mathrm{ppm})$ & 0.31 \\
$\mathrm{Zn}(\mathrm{ppm})$ & 2.85 \\
$\mathrm{Cd}(\mathrm{ppm})$ & 1.81 \\
$\mathrm{~Pb}(\mathrm{ppm})$ & 0.33 \\
$\mathrm{Cr}(\mathrm{ppm})$ & 1.39 \\
\hline
\end{tabular}

Table 2 Combinations of experimental groups

\begin{tabular}{|c|c|c|c|c|c|}
\hline Groups & 1. dose & 2. dose & 3. dose & 4. dose & Total \\
\hline Control & Soil & Soil & Soil & Soil & Soil \\
\hline G1 & $60 \mathrm{~g} \mathrm{Z}(60 \times 3)$ & - & - & - & $180 \mathrm{~g} \mathrm{Z}$ \\
\hline $\mathrm{G} 2$ & $30 \mathrm{~g} \mathrm{Z}(30 \times 3)+420 \mathrm{ml} \mathrm{LF}$ & $420 \mathrm{ml} \mathrm{LF}$ & $150 \mathrm{ml} \mathrm{LF}$ & $150 \mathrm{ml} \mathrm{LF}$ & $90 \mathrm{~g} \mathrm{Z}+1140 \mathrm{ml} \mathrm{LF}$ \\
\hline G3 & $60 \mathrm{~g} \mathrm{Z}(60 \times 3)+210 \mathrm{ml} \mathrm{LF}$ & $210 \mathrm{ml} \mathrm{LF}$ & $100 \mathrm{ml} \mathrm{LF}$ & $100 \mathrm{ml} \mathrm{LF}$ & $180 \mathrm{~g} \mathrm{Z}+620 \mathrm{ml} \mathrm{LF}$ \\
\hline G4 & $90 \mathrm{~g} \mathrm{Z}(90 \times 3)+105 \mathrm{ml} \mathrm{LF}$ & $105 \mathrm{ml} \mathrm{LF}$ & $50 \mathrm{ml} \mathrm{LF}$ & $50 \mathrm{ml} \mathrm{LF}$ & $270 \mathrm{~g} \mathrm{Z}+310 \mathrm{ml} \mathrm{LF}$ \\
\hline G5 & $210 \mathrm{ml} \mathrm{LF}$ & $210 \mathrm{ml} \mathrm{LF}$ & $100 \mathrm{ml} \mathrm{LF}$ & $100 \mathrm{ml} \mathrm{LF}$ & $620 \mathrm{ml} \mathrm{LF}$ \\
\hline
\end{tabular}

LF: Liquid fertilizer, Z: Zeolite

Seeding was done by hand in depth of 5-6 $\mathrm{cm}$ and 30 seeds/ pot. Together with sowing, the first liquid fertilizer and zeolite doses were applied to the soil according to the groups. Seaweed liquid fertilization was implemented for total of 4 times with different concentrations in each treatment group. These concentrations of the first two applications were applied to the soil directly and the last two applications were on the foliage by spraying.
Germination, seedling and yield time of cucumber plants were observed and measurements of yield's weights were recorded during the experimental period. When the germination is completed, at the seedling stage, each pot was left with only three saplings. The weight of the seedlings which removed from the soil were measured and recorded according to the groups in the laboratory environment (Table 4). Twenty four days after the first 
germination, the second SLF application was applied to the soil (Table 2). Five days after the first flowering, the third SLF application was applied to the leaf by the spraying (Table 2). Finally, the fourth SLF application was applied to the leaf 5 days after the first products were obtained (Table 2). The experiment groups were observed every two days, irrigation was done and the weeds were removed regularly. Cucumbers reaching to the market size were harvested by hand and weight measurements were made according to the groups in the laboratory. While some of soil and liquid fertilizer material analyses used in the experiment were performed by a Private Laboratory and some of them were performed by Giresun University
Central Research Laboratory Research and Application Center. Soil and liquid fertilizer samples, the levels of $\mathrm{Mn}$, $\mathrm{Fe}, \mathrm{Co}, \mathrm{Ni}, \mathrm{Cu}, \mathrm{Zn}, \mathrm{As}, \mathrm{Cd}, \mathrm{Pb}, \mathrm{Cr}$ and Se were analysed as ppm by ICP-MS. $\mathrm{K}_{2} \mathrm{O}$ levels were analysed as percentage by ICP-OES and $\mathrm{pH}$ by TS ISO 10390. In liquid fertilizer samples, total humic + fulvic acid was analysed by TS 5869 ISO 5073 as percentage and N levels by elemental analysis as percentage and $\mathrm{Cl}$ levels as percentage, $\mathrm{C}$ levels by Elemental Analyzer as percentage, B levels by ICPOES as ppm. The mean and standard error values of soil analysis were calculated. The data were analysed by oneway analysis of variance and Duncan test.

Table 3 Germination rates by groups (\%)

\begin{tabular}{l|cccccc}
\hline \multicolumn{1}{c}{ Groups } & $1^{\text {th }}$ day & $2^{\text {th }}$ day & $3^{\text {th }}$ day & $4^{\text {th }}$ day & $5^{\text {th }}$ day & $6^{\text {th }}$ day \\
\hline Control & $72.2 \pm 6.76$ & $80.0 \pm 10.2$ & $80.0 \pm 10.2$ & $80.0 \pm 10.2$ & $81.1 \pm 10.9$ & $81.1 \pm 10.9$ \\
G1 & $88.9 \pm 4.01$ & $91.1 \pm 4.01$ & $91.1 \pm 4.01$ & $92.2 \pm 2.94$ & $93.3 \pm 3.85$ & $94.4 \pm 2.94$ \\
G2 & $84.4 \pm 4.01$ & $90.0 \pm 3.85$ & $90.0 \pm 3.85$ & $90.0 \pm 3.85$ & $90.0 \pm 3.85$ & $90.0 \pm 3.85$ \\
G3 & $77.8 \pm 5.88$ & $82.2 \pm 8.68$ & $86.6 \pm 6.94$ & $87.8 \pm 6.19$ & $87.8 \pm 6.19$ & $88.9 \pm 5.88$ \\
G4 & $77.8 \pm 12.3$ & $83.3 \pm 11.7$ & $83.3 \pm 11.7$ & $83.3 \pm 11.7$ & $85.6 \pm 9.49$ & $85.6 \pm 9.49$ \\
G5 & $83.3 \pm 8.39$ & $90.0 \pm 6.67$ & $90.0 \pm 6.67$ & $91.1 \pm 5.56$ & $92.2 \pm 6.19$ & $92.2 \pm 6.19$ \\
\hline
\end{tabular}

Table 4 Seedling weights according to groups

\begin{tabular}{l|c}
\hline \multicolumn{1}{c|}{ Groups } & Weights $(\mathrm{g})$ \\
\hline Control & $1.38 \pm 0.06$ \\
G1 & $1.31 \pm 0.04$ \\
G2 & $1.20 \pm 0.03$ \\
G3 & $1.81 \pm 0.26$ \\
G4 & $1.29 \pm 0.04$ \\
G5 & $1.29 \pm 0.05$ \\
\hline
\end{tabular}

\section{Results and Discussion}

The chemical analysis results of the seaweed liquid fertilizer used in the experiment given on Table 1. The average values of the analysed seaweed liquid fertilizer are as follows: $\mathrm{N}(\%)$ : 0.16 ; $\mathrm{C} \mathrm{( \% ):} \mathrm{1.24;} \mathrm{total} \mathrm{humic+fulvic}$ acid (\%): $25.5 ; \mathrm{K}_{2} \mathrm{O}$ soluble in water $(\%): 0.14 ; \mathrm{Cl}(\%)$ : 0.26; pH: 8.0; P (ppm): 0.07; total B (ppm): 172; Se (ppm): 1.68; $\mathrm{Mn}$ (ppm): 2.20; Fe (ppm): 61.5; Co (ppm): 0.47; Ni (ppm): 0.14; $\mathrm{Cu}$ (ppm): 0.31; Zn (ppm): 2.85; Cd (ppm): 1.81; Pb: 0.33; Cr (ppm): 1.39. Türkmen and Kütük (2017), notified that the amount of $\mathrm{N}$ content of compost obtained by brown seaweed was 3.19 in study that they in this study, the average germination time of Cucumis sativus was determined as 6 days. The first germination started on the fourth day after sowing and the germination rates was given on the Table 3 . When the tables were examined, it was seen that the highest ratio was in G1 with $88,9 \%$ in the first day of germination and it was in the control group with the lowest rate of $72.2 \%$. While the lowest rate was observed in the control group from the first day to the sixth day, the highest rate was observed in the G1 (60 g zeolite) group. At the end of the sixth day, the highest germination rates according to the groups were found as follows. Control: 81,1\%; G1: 94.4\%; G2: 90\%; G3: 88.9\%; G4: 85.6\%; G5: 92.2\% (Table 3). Kurama et al. (1999), notified that the germination in seeds, plant growth and the aspect of development increased, implementing some plants to the artificial zeolites that the fertilizer was impregnated and the natural zeolites which had aspect of high absorption. Demir et al. (2006), in the germination of tomato, pepper and aubergine seeds reported that there was the positive effect of the suspension obtained by alga. Demirkaya (2010), pointed out that it reduced the average germination time while the applications of alga extract and osmotic conditioning were increasing the germination percentage in onion and pepper seeds. Akyurt et al. (2011), fermented liquid organic fertilizer obtained by sea lettuce (Ulva sp.) was effective in germination of broccoli seeds. Hernández - Herrara et al. (2014) reported that the germination rate of tomato seeds operationalized by Ulva lactuca and Padina gymnospora extracts increased at low concentrations.

Average seedling yield according to groups; the control was determined as $1.38 \mathrm{~g}$; G1: $1.31 \mathrm{~g}$; G2: $1.20 \mathrm{~g}$; G3: 1.81 g; G4: 1.29 g; G5: 1.29 g. The maximum seedling yield was observed in $\mathrm{G} 3$ with $1.81 \mathrm{~g}$, $(60 \mathrm{~g}$ zeolite $+620 \mathrm{ml}$ liquid fertilizer), the minimum was observed with $1.20 \mathrm{~g}$ in G2, (30 g zeolite $+1140 \mathrm{ml}$ liquid fertilizer) (Table 4). Lakshmi and Sundaramoorthy (2010), notified that alga extracts were more effective than chemical fertilizers in increasing the growth of seedlings in a study they made with the liquid fertilizer of Ulva lactuca. In one study, it was observed that liquid alga fertilizer was obtained by Sargassum plagiophyllum invented the germination and early seedling growth (Zodape, 2001).

Average weights according to groups of cucumbers obtained during harvest given on Table 5. According to the table, while the maximum weight was in G4 (90 g zeolite $+310 \mathrm{ml}$ liquid fertilizer) with $179 \mathrm{~g}$, the minimum one appared in G5 (620 ml liquid fertilizer) with $133 \mathrm{~g}$. Cassan 
et al. (1992), notified that Goemar GA, an Ascophyllum nodosum extract, applied as spraying to spinach plant increased the amount of fresh weight in spinach. Eyras et al. (1998), reported that compost obtained by alga increased the water holding capacity and plant growth. Zahid (1999), in his study, reported that compost obtained by Codium lyengarli significantly increased the growth rate of some plants. Zodape et al. (2008) notified that the seaweed liquid fertilizer obtained by Kappaphycus alvarezii was implemented as leaf spray $(2.5 \%)$ increased the yield and food quality in the okra fruit. Rathore et al. (2009) observed that the liquid alga extract obtained by Kappaphycus Alvezii was implemented as leaf spray increased the yield in soybean. Sathya et al. (2010) notified that SLF concentration of $30 \%$ prepared from Chaetomorpha linum showed the maximum growth on Cajanus cajan. Castellanos -Barriga et al. (2017) reported that it indicated the best yield in low concentration $(0.2 \%)$, testing on its biochemical parameters and growth, the germination of mung bean to the different concentrations of seaweed liquid fertilizer obtained by Ulva lactucamade. Eyras et al. (1998), pointed out that the value of $C$ content of compost obtained by seaweed was $\% 1.8$ in study that they made. Lai et al. (2008), notified the value of humic acid of organic fertilizer was $\% 9.2$ in a study that they made with hog manure. Demirtaş et al. (2012), identified that the value of the water soluble $\mathrm{K}_{2} \mathrm{O}$ of the liquid organic fertilizer obtained by some plants was $1 \%$. Akyurt et al (2011), notified that the value of $\mathrm{pH}$ of the liquid organic fertilizer obtained by Ulva sp. was 6.4. Kavuk (2013), notified that the $\mathrm{Ni}$ content of liquid suspense organic fertilizer obtained by Caralline elongata was 0,1 ppm. Koç (2013), in his study, determined that Mn of the liquid fermented fertilizer obtained by Ulva lactuca was $1.6 \mathrm{ppm}$. Demir et al. (2003), notified that Fe value of fertilizer obtained by seaweed was $1810 \mathrm{ppm}$.

Table 5 Weight of cucumber plant obtained during harvest

\begin{tabular}{l|c}
\hline \multicolumn{1}{c|}{ Groups } & Weights (g) \\
\hline Control & $144 \pm 11.9$ \\
G1 & $145 \pm 18.9$ \\
G2 & $169 \pm 15.9$ \\
G3 & $178 \pm 14.7$ \\
G4 & $179 \pm 15.6$ \\
G5 & $133 \pm 10.2$ \\
\hline
\end{tabular}

Table 6 Soil analysis results of experimental groups

\begin{tabular}{l|llllll}
\hline \multicolumn{1}{c|}{ Parameters } & \multicolumn{1}{c}{ Control } & \multicolumn{1}{c}{ G1 } & \multicolumn{1}{c}{ G2 } & \multicolumn{1}{c}{ G3 } & G4 & G5 \\
\hline $\mathrm{C}(\%)$ & $0.87 \pm 0.04^{\mathrm{b}}$ & $0.48 \pm 0.10^{\mathrm{a}}$ & $0.68 \pm 0.04^{\mathrm{ab}}$ & $0.64 \pm 0.11^{\mathrm{ab}}$ & $0.6 \pm 0.05^{\mathrm{a}}$ & $0.87 \pm 0.07^{\mathrm{b}}$ \\
$\mathrm{Na}(\mathrm{ppm})$ & $3,17 \pm 0,58^{\mathrm{a}}$ & $3,40 \pm 0,17^{\mathrm{a}}$ & $2,83 \pm 1,13^{\mathrm{a}}$ & $2,90 \pm 0,61^{\mathrm{a}}$ & $3,43 \pm 0,52^{\mathrm{a}}$ & $3,67 \pm 0,07^{\mathrm{a}}$ \\
$\mathrm{K}_{2} \mathrm{O}(\mathrm{ppm})$ & $141 \pm 2.36^{\mathrm{b}}$ & $150 \pm 2.86^{\mathrm{c}}$ & $158 \pm 2.68^{\mathrm{c}}$ & $198 \pm 3.63^{\mathrm{d}}$ & $191 \pm 2.46^{\mathrm{d}}$ & $128 \pm 1.76^{\mathrm{a}}$ \\
$\mathrm{EC}(\mathrm{dS} / \mathrm{m})$ & $0.30 \pm 0.06^{\mathrm{a}}$ & $0.23 \pm 0.03^{\mathrm{a}}$ & $0.27 \pm 0.03^{\mathrm{a}}$ & $0.20 \pm 0.00^{\mathrm{a}}$ & $0.30 \pm 0.00^{\mathrm{a}}$ & $0.23 \pm 0.03^{\mathrm{a}}$ \\
$\mathrm{Lime}(\%)$ & $0.54 \pm 0.05^{\mathrm{b}}$ & $0.74 \pm 0.09^{\mathrm{bc}}$ & $0.54 \pm 0.05^{\mathrm{b}}$ & $0.79 \pm 0.05^{\mathrm{c}}$ & $0.79 \pm 0.05^{\mathrm{c}}$ & $0.30 \pm 0.09^{\mathrm{a}}$ \\
$\mathrm{P}(\mathrm{ppm})$ & $0.19 \pm 0.07^{\mathrm{a}}$ & $0.11 \pm 0.01^{\mathrm{a}}$ & $0.13 \pm 0.03^{\mathrm{a}}$ & $0.08 \pm 0.01^{\mathrm{a}}$ & $0.03 \pm 0.19^{\mathrm{a}}$ & $0.16 \pm 0.07^{\mathrm{a}}$ \\
$\mathrm{B}$ & $<0.005$ & $<0.005$ & $<0.005$ & $<0.005$ & $<0.005$ & $<0.005$ \\
$\mathrm{pH}$ & $5.07 \pm 0.07^{\mathrm{a}}$ & $5.03 \pm 0.03^{\mathrm{a}}$ & $5.10 \pm 0.00^{\mathrm{a}}$ & $5.00 \pm 0.00^{\mathrm{a}}$ & $5.10 \pm 0.06^{\mathrm{a}}$ & $5.03 \pm 0.03^{\mathrm{a}}$ \\
$\mathrm{Se}(\mathrm{ppm})$ & $0.25 \pm 0.01^{\mathrm{b}}$ & $0.23 \pm 0.03^{\mathrm{b}}$ & $0.19 \pm 0.02^{\mathrm{ab}}$ & $0.18 \pm 0.01^{\mathrm{ab}}$ & $0.15 \pm 0.01^{\mathrm{a}}$ & $0.13 \pm 0.03^{\mathrm{a}}$ \\
\hline
\end{tabular}

Differences among the values expressed horizontally by the different letters are statistically meaningful $(\mathrm{P}<0.05)$.

Table 7 Heavy metal analysis results of experiment soils according to groups.

\begin{tabular}{l|llllll}
\hline \multicolumn{1}{c}{ Parameters } & \multicolumn{1}{c}{ Control } & G1 & G2 & G3 & G4 & G5 \\
\hline Mn (ppm) & $564 \pm 45.9^{\mathrm{a}}$ & $547 \pm 29.7^{\mathrm{a}}$ & $533 \pm 174^{\mathrm{a}}$ & $714 \pm 340^{\mathrm{a}}$ & $492 \pm 37.3^{\mathrm{a}}$ & $480 \pm 107^{\mathrm{a}}$ \\
$\mathrm{Fe}(\mathrm{ppm})$ & $7436 \pm 247^{\mathrm{b}}$ & $7574 \pm 361^{\mathrm{b}}$ & $7172 \pm 387^{\mathrm{b}}$ & $7587 \pm 336^{\mathrm{b}}$ & $7681 \pm 385^{\mathrm{b}}$ & $5924 \pm 562^{\mathrm{a}}$ \\
$\mathrm{Cu}(\mathrm{ppm})$ & $9.26 \pm 0.41^{\mathrm{a}}$ & $9.08 \pm 0.55^{\mathrm{a}}$ & $8.79 \pm 0.35^{\mathrm{a}}$ & $8.88 \pm 0.45^{\mathrm{a}}$ & $9.75 \pm 0.37^{\mathrm{a}}$ & $8.26 \pm 0.68^{\mathrm{a}}$ \\
$\mathrm{Co}(\mathrm{ppm})$ & $6.30 \pm 0.35^{\mathrm{a}}$ & $7.01 \pm 0.07^{\mathrm{a}}$ & $7.45 \pm 2.03^{\mathrm{a}}$ & $13.3 \pm 7.58^{\mathrm{a}}$ & $7.02 \pm 0.54^{\mathrm{a}}$ & $7.30 \pm 1.85^{\mathrm{a}}$ \\
$\mathrm{Ni}(\mathrm{ppm})$ & $3.35 \pm 0.17^{\mathrm{a}}$ & $3.26 \pm 0.19^{\mathrm{a}}$ & $3.33 \pm 0.21^{\mathrm{a}}$ & $3.60 \pm 0.18^{\mathrm{a}}$ & $3.63 \pm 0.06^{\mathrm{a}}$ & $3.21 \pm 0.54^{\mathrm{a}}$ \\
$\mathrm{Zn}(\mathrm{ppm})$ & $16 \pm 0.7^{\mathrm{a}}$ & $15.8 \pm 0.69^{\mathrm{a}}$ & $16 \pm 1.1^{\mathrm{a}}$ & $15.9 \pm 1.18^{\mathrm{a}}$ & $16.7 \pm 0.55^{\mathrm{a}}$ & $15.5 \pm 1.87^{\mathrm{a}}$ \\
$\mathrm{As}(\mathrm{ppm})$ & $4.27 \pm 0.13^{\mathrm{ab}}$ & $4.51 \pm 0.26^{\mathrm{b}}$ & $4.48 \pm 0.71^{\mathrm{b}}$ & $4.30 \pm 0.23^{\mathrm{ab}}$ & $4.67 \pm 0.23^{\mathrm{b}}$ & $3.19 \pm 0.30^{\mathrm{a}}$ \\
$\mathrm{Cd}(\mathrm{ppm})$ & $0.03 \pm 0.01^{\mathrm{a}}$ & $0.11 \pm 0.06^{\mathrm{a}}$ & $0.20 \pm 0.06^{\mathrm{a}}$ & $0.03 \pm 0.01^{\mathrm{a}}$ & $0.03 \pm 0.01^{\mathrm{a}}$ & $0.43 \pm 0.01^{\mathrm{a}}$ \\
$\mathrm{Pb}(\mathrm{ppm})$ & $11.6 \pm 0.39^{\mathrm{a}}$ & $12.7 \pm 0.38^{\mathrm{a}}$ & $11.9 \pm 2.05^{\mathrm{a}}$ & $16.3 \pm 5.44^{\mathrm{a}}$ & $12.1 \pm 0.38^{\mathrm{a}}$ & $11.7 \pm 1.04^{\mathrm{a}}$ \\
$\mathrm{Cr}(\mathrm{ppm})$ & $7.77 \pm 0.27^{\mathrm{ab}}$ & $7.96 \pm 0.34^{\mathrm{b}}$ & $7.06 \pm 0.54^{\mathrm{ab}}$ & $8.65 \pm 0.44^{\mathrm{b}}$ & $8.09 \pm 0.71^{\mathrm{b}}$ & $6.09 \pm 0.77^{\mathrm{a}}$ \\
\hline
\end{tabular}

"Differences among the values expressed horizontally by the different letters are statistically meaningful $(\mathrm{P}<0.05)$.

The physical and chemical analysis results of the soil used in the experiment according to the groups given on Table 6,7 . While carbon was in the minimum with $0.48 \%$ in $\mathrm{G} 1$ group, it owns the maximum value with $0.87 \%$ in the control group. In a study by Edmeades (2003), the value of $\mathrm{C}$ in the soil that $\mathrm{N}, \mathrm{P}, \mathrm{K}$ fertilizer was implemented was notified as $0.78 \%$. Lazcano et al. (2011), notified that $\mathrm{C}$ value of the soil used in the experiment was $3.01 \%$ in a study that they made with vermicompost. While sodium is the minimum with $2,83 \mathrm{ppm}$ in the $\mathrm{G} 2$ group, it owns the maximum value with $3,67 \mathrm{ppm}$ in the G5 group. The maximum $\mathrm{K}_{2} \mathrm{O}$ value was observed as 198 ppm in $\mathrm{G} 3$, the minimum value in G5 was observed as $128 \mathrm{ppm}$. While the lowest level of EC appeared in G3 with $0.20 \mathrm{dS} / \mathrm{M}$, the 
highest one was observed with $0.30 \mathrm{dS} / \mathrm{M}$ in $\mathrm{G} 4$ and control group. Alagöz et al. (2006), notified that the EC level of the soil was $0.90 \mathrm{dS} / \mathrm{m}$ in a study that they made with the cultivated leonardite at the rate of $100 \mathrm{~kg} / \mathrm{ha}$. Lime is the minimum with $0.30 \%$ in G5 but it owns the maximum value with $0.79 \%$ in G3 and G4. Türkmen and Kütük (2017), notified that the lime content of soil was $1.62 \%$ in a study that they made with compost, zeolite and chemical fertilizers. While Phosphorus is the minimum value with $0.03 \mathrm{ppm}$ in G4 it owns maximum value with $0.19 \mathrm{ppm}$ in the control group. While the lowest $\mathrm{pH}$ content in G3 was 5.00, the highest pH content in G2 and G4 was observed as 5.10. Demirkiran and Cengiz (2011), pointed out that the level of $\mathrm{pH}$ in soil used in the experiment was 7.6 in a study that they made with the different organic materials and chemical fertilizer. While selenium is the minimum with $0.13 \mathrm{ppm}$ in G5, it owns the maximum value with $0.25 \mathrm{ppm}$ in the control group. Toxic effects are able to appear in the situations that the extractable heavy metal concentration in soils for selenium is over $10 \mathrm{ppm}$ (Y1ld1z, 2001).

The statistical analysis of the soil used in the experiment were given on Table 6. Parameters appearing in the highest amount in the experiment groups are as follows; C, EC, P, Se in the control group; $\mathrm{pH}$ in $\mathrm{G} 2$ group; $\mathrm{K}_{2} \mathrm{O}$ and lime in $\mathrm{G} 3$ group; $\mathrm{EC}$, lime and $\mathrm{pH}$ in $\mathrm{G} 4$ group; $\mathrm{C}$ and $\mathrm{Na}$ in G5 group. While differences between the groups were statistically important for the parameters of $\mathrm{C}$, $\mathrm{K}_{2} \mathrm{O}$, lime and Se, difference between the other parameters was not identified.

According to the experiment groups, the heavy metal contents of soil samples given on Table 7. While Mn is the minimum with $480 \mathrm{ppm}$ in G5, it owns the maximum value with 714 ppm in the G3 group. In one study, researchers notified that the value of Mn that was useful to the plant of soil used in the experiment was $295,80 \mathrm{ppm}$ and they investigated for the effect that's above tomato of copper implemented through soil (Sönmez et al. 2006). Iron is the minimum with 5924 ppm in G5, it owns the maximum value with $7681 \mathrm{ppm}$ in G4. Fe concentration in soil solution is in between $30-550 \mathrm{ppm}$. In addition, it can exceed 2000 ppm in acidic soils and toxic effects can appear (Bakırcıoglu, 2009). While copper is the minimum with 8.26 ppm in G5, it owns the maximum value with 9.75 ppm in G4. Akyurt et al (2011), determined that the amount of copper in the soil that the liquid organic fertilizer obtained by Ulva sp. was used was $15.80 \mathrm{ppm}$. While cobalt is the minimum with $6.30 \mathrm{ppm}$ in control group, it owns the maximum value with $13.3 \mathrm{ppm}$ in the G3 group. Toxic effects can appear in situation that extractable heavy metal concentration in soils for cobalt is above $10 \mathrm{ppm}$ (Yildiz, 2001). While Nickel is the minimum with 3.21 ppm in G5, it owns the maximum value with $3.63 \mathrm{ppm}$ in $\mathrm{G} 4$. In a study made, it has been notified that lantern grass and mullein plants could be used in the purity of soils polluted by the heavy metals and the receivable Ni content in soil was 7.34 ppm (Eren and Mert, 2016). While zinc is the minimum with $15.5 \mathrm{ppm}$ in the G5 group, it owns the maximum value with $16.7 \mathrm{ppm}$ in the G4 group. CabelloConejo et al. (2014), notified that the amount of $\mathrm{Zn}$ in soil that phytohormone was implemented was $28.4 \mathrm{ppm}$ in a study that they made. Arsenic is the minimum with 3.19 ppm in G5, it owns the maximum value with $4.67 \mathrm{ppm}$ in
G4. Güven et al. (2004), notified that the average value was around 5 ppm while the concentration of arsenic soil in soil was changing between 1-40 ppm. Cadmium owns the maximum value with $0.43 \mathrm{ppm}$ in G5 on the other hand, it is the minimum with $0.03 \mathrm{ppm}$ in G4, G3 and control group. Beesley et al. (2010), notified that $\mathrm{Cd}$ value of compost added soil was $0.37 \mathrm{ppm}$ in a study that they made with simple field experiment. While lead is the minimum with $11.6 \mathrm{ppm}$ in control group, it owns the maximum value with 16.3 ppm in G3 group. Asri and Sonmez (2006), pointed out that it did not cause danger in terms of human and plant health that the amount of $\mathrm{Pb}$ in soil was in the range of $15-40 \mathrm{ppm}$. While chromium is the minimum with $6,09 \mathrm{ppm}$ in G5, it owns the maximum value with $8.65 \mathrm{ppm}$ in G3. Kahvecioglu et al. (2003), notified that this value got to $4000 \mathrm{ppm}$ in the unpolluted some soils while chrome in lots of soils was in the range of 2-60 ppm. If these data are considered, it was observed that the elements of $\mathrm{Mn}$, $\mathrm{Fe}, \mathrm{Cu}, \mathrm{Co}, \mathrm{Ni}, \mathrm{Zn}, \mathrm{As}, \mathrm{Pb}$ and $\mathrm{Cr}$ in soil that liquid fertilizer was just added were found less than the other groups.

The statistical analyses of the heavy metal content of the experiment results of soils which belonged to the groups were given on Table 7 . The parameters appearing in the maximum content in the experiment groups are: $\mathrm{Mn}$, $\mathrm{Co}, \mathrm{Pb}$ and $\mathrm{Cr}$ in the $\mathrm{G} 3$ group; $\mathrm{Fe}, \mathrm{Cu}, \mathrm{Ni}, \mathrm{Zn}$, As in the G4 group; Cd in the G5 group. While the differences between the groups were statistically meaningful for the elements of $\mathrm{Fe}$, As and $\mathrm{Cr}$, the difference between the other parameters didn't appear.

The germination rate in cucumber plant was in the minimum control group, the maximum one was determinate in G1 group and the soil analysis results of these groups were compared. The parameters of $\mathrm{C}(\%), \mathrm{EC}$ $(\mathrm{dS} / \mathrm{m}), \mathrm{P}(\mathrm{ppm}), \mathrm{pH}, \mathrm{Se}(\mathrm{ppm})$ in $\mathrm{G} 1$ group were identified lower than the control group. However the parameters of lime $(\%), \mathrm{Na}(\mathrm{ppm}), \mathrm{K}_{2} \mathrm{O}(\%)$ in control group were identified lower than G1 group (Table 6). The elements of $\mathrm{Mn}, \mathrm{Cu}, \mathrm{Ni}, \mathrm{Zn}$ in $\mathrm{G} 1$ group were identified lower than the control group. The elements of Fe, $\mathrm{Co}, \mathrm{As}, \mathrm{Cd}, \mathrm{Pb}, \mathrm{Cr}$ in the control group were lower than the G1 (Table 7). The Germination rates in G1group that $60 \mathrm{~g}$ zeolite was just used appeared higher than other groups (Table 3). It can be explained by zeolite invents the germination that there is more germination in G1 group than the other groups. The seedling weight of cucumber plant was analysed, in the minimum weight was G2 group, the maximum weight was appeared in G3 group. When the soil analysis results of these groups were compared, the parameters of $\mathrm{C}(\%), \mathrm{EC}$ (dS / m), P (ppm), pH and Se (ppm) in the G3 group appeared lower than the G2 group. However, the parameters of lime (\%), $\mathrm{Na}(\mathrm{ppm})$ and $\mathrm{K}_{2} \mathrm{O}(\%)$ in the $\mathrm{G} 2$ group were identified lower than the G3 group. The elements of $\mathrm{Mn}, \mathrm{Fe}, \mathrm{Cu}, \mathrm{Co}, \mathrm{Ni}, \mathrm{Pb}, \mathrm{Cr}$ in the $\mathrm{G} 2$ group appeared lower than the G3 group. However, elements of As and $\mathrm{Cd}$ in the G3 group were identified lower than the $\mathrm{G} 2$ group. While $60 \mathrm{~g}$ zeolite $+620 \mathrm{ml}$ organic liquid fertilizer was used as material in G3 group, $30 \mathrm{~g}$ zeolite + $1140 \mathrm{ml}$ organic liquid fertilizer was used in G2 group. If these data are considered, the use of G3 group ( $60 \mathrm{~g}$ zeolite $+620 \mathrm{ml}$ liquid fertilizer) for seedling yield can be suggested. The total harvest yield was in the maximum G4 group and it appared as minimum in G5 group, the soil 
analysis results of these groups were compared. The parameters of $\mathrm{K}_{2} \mathrm{O}(\%)$, EC (dS/m), lime (\%), pH, Se (ppm) in $\mathrm{G} 4$ group appeared lower than the G5 group. And also the elements of $\mathrm{C}(\%), \mathrm{P}(\mathrm{ppm})$ and $\mathrm{Na}(\mathrm{ppm})$ in $\mathrm{G} 5$ group appeared lower than the $\mathrm{G} 4$ group. While the elements of $\mathrm{Co}$ and $\mathrm{Cd}$ in the $\mathrm{G} 4$ group appeared lower than the G5 group. However, elements of $\mathrm{Mn}, \mathrm{Fe}, \mathrm{Cu}, \mathrm{Ni}, \mathrm{Zn}, \mathrm{As}, \mathrm{Pb}$, $\mathrm{Cr}$ in the G5 group were identified lower than the G4 group. However, while $90 \mathrm{~g}$ zeolite $+310 \mathrm{ml}$ organic liquid fertilizer was used in G4 group, $620 \mathrm{ml}$ liquid fertilizer was just used as material in G5 group. If these data are considered, the G4 group (90 g zeolite $+310 \mathrm{ml}$ liquid fertilizer) for cucumber yield can be suggested.

According to the results which was obtained in this study, the seaweed liquid fertilizer obtained by Ulva lactuca can be said to affect the yield of cucumber plant positively. However, it has been causing the challenges if the alga raw-material is under the need while being used as fertilizer. That's why the studies about the cultivation of Alga can be provided to be included in Agriculture by getting invented. The results of study has showed that the turning the seaweed liquid fertilizer combined by zeolite into a valuable product to be used in agriculture is possible. It can be said that it will contribute to that an important environment issue for the shores gets solved and also the productivity of agricultural lands increases. This product can be used as fertilizer in ecological agriculture systems because it can't be limited and is natural origin.

\section{Acknowledgements}

Thanks to Giresun University Scientific Project Office for its financial support (Project No: FEN-BAP-A-200515-81).

\section{References}

Akyurt İ, Şahin Y, Koç H. 2011. Evaluation of Ulva lactuca as a Liquid Organic Fertilizer. The Black Sea J of Sci, 2 (2): 55-62

Alagöz Z, Y1lmaz E, Öktüren F. 2006. Effects of Organic Material Addition on Some Physical and Chemical Properties of Soils. Med Agric Sci, 19 (2): 245- 254. DOI: 10.31195/ejejfs.511098

Asri FÖ, Sönmez S. 2006. The Effect of Heavy Metal Toxicity on Plant Metabolism. Derim, 23(2): 36-45.

Bakırcıoğlu D. 2009. Determination of Macro and Micro Elements in Soil. Trakya University, Graduate School of Sciences, Chemistry Program, Doctoral dissertation pp.51, Trakya.

Beesley L, Moreno-Jiménez E, Gomez-Eyles JL. 2010. Effects of biochar and greenwaste compost amendments on mobility, bioavailability and toxicity of inorganic and organic contaminants in a multi-element polluted soil. Environmental pollution, 158(6): 2282-2287. DOI: 10.1016/j.envpol. 2010.02.003

Bhosle NB, Untawale AG, Dhargalkar VK. 1975. Effect of Seaweed Extract on the Growth of Phaseolus vulgaris L. National İnstitute of Oceanography, 4 (2): 208-210.

Cabello-Conejo MI, Prieto-Fernández Á, Kidd PS. 2014. Exogenous treatments with phytohormones can improve growth and nickel yield of hyperaccumulating plants. Science of the Total Environment, 494-495: 1-8. DOI: 10.1016/ j.scitotenv.2014.06.102

Cassan L, Jeannin I, Lamaze T, Morot-Gaudry JF. 1992. The Effect of the Ascophyllum nodosum Extract Goëmar GA 14 on the Growth of Spinach. Botanica Marina, 35 (5): 437- 440. DOI: 10.1515/botm.1992.35.5.437
Castellanos-Barriga LG, Santacruz-Ruvalcaba F, Hernández Carmona G, Ramírez-Briones E, Hernández-Herrera RM. 2017. Effect of seaweed liquid extracts from Ulva lactuca on seedling growth of mung bean (Vigna radiata). Journal of Applied Phycology, 29(5): 2479-2488. DOI: doi:10.1007 /s10811-017-1082-x

Demir H, Gölükçü M, Topuz A, Özdemir F, Polat E, Şahin H. 2003. The Effect of Different Organic Fertilizers on the Mineral Contents of Yedikule and Iceberg Lettuce Types Grown in Organic Farming. Med Agric Sci, 16 (1): 79-85.

Demir N, Dural B, Yildirim K. 2006. Effect of Seaweed Suspensions on Seed Germination of Tomato, Pepper and Aubergine. J Biol Sci, 6 (6): 1130-1133. DOI: 10.3923/jbs.2006.1130.1133

Demirkaya M. 2010. Effects of Seaweed (Ascophyllum nodosum) extract application on viability and vigour of pepper and onion seeds. ERU J of the Inst of Sci and Tech, 26 (3): 217 - 224.

Demirkıran AR, Cengiz MÇ. 2011, Effects of Organic Materials, as Gyttja, Alsil, Alga, Humic Acid, Moss, Straw, Peat and Chemical Fertilizers Treatments on the Pistacia Vera L. Seedling. Bingöl Science Journal of Bingöl University, 1 (1): 43-50.

Demirtaş EI, Özkan CF, Asri FÖ, Nuri ARI. 2012. The Effects of Some Organic and Chemical Fertilizer Applications on the Yield and Quality of Tomato. Alatarım, 11 (2): 9-16.

Dhargalkar VK, Pereira N. 2005. Seaweed: Promising Plant of the Millennium. Science and Culture. 71: 3-10.

Edmeades DC. 2003. The Long-Term Effects of Manures and Fertilisers on Soil Productivity and Quality: A Review. Nutrient cycling in Agroecosystems, 66 (2): 165-180. DOI: 10.1023/A:1023999816690

Eren A, Mert M. 2016. The Effect of Heavy Metal Applications $(\mathrm{Ni}, \mathrm{Cd}$ and $\mathrm{Cu}$ ) on Growth and Development of Elecampane, Groundcherry and Mullein. Turkish J of Agric Res, 4 (1): 5058.

Eyras MC, Rostagno CM, Defossé GE. 1998. Biological Evaluation of Seaweed Composting. Compost Science \& Utilization, 6(4): 74-81. DOI: 10.1080/1065657X.1998. 10701943.

Gülen J, Zorbay F, Arslan S. 2012. Zeolites and Usage Areas. Karaelmas Science and Engineering Journal, 2 (1): 63-68. DOI: $10.7212 \% 2 F z k u f b d . v 2 i 1.80$.

Güven A, Kahvecioğlu Ö, Kartal G, Timur S. 2004. Metallerin çevresel etkileri-III. Metalurji Dergisi, 138: 64-71.

Hernández-Herrera RM, Santacruz-Ruvalcaba F, Ruiz-López M. A, Norrie J, Hernández-Carmona G. 2014. Effect of Liquid Seaweed Extracts on Growth of Tomato Seedlings (Solanum lycopersicum L.). Journal of Applied Phycology, 26 (1): 619628. DOI: 10.1007/s10811-013-0078-4.

Kahvecioğlu Ö, Kartal G, Güven A, Timur S. 2003. Metallerin çevresel etkileri-I. Metalurji Dergisi, 136: 47-53.

Kaliaperumal N, Chennubhotla VS, Kalimuthu S. 1987. Seaweed resources of India. CMFRI Bulletin, 41: 51-54.

Kavuk E. 2013. Manufacturing of Suspended Organic Fertilizer From Some Marine Macroalgae (Ulva sp., Cystoseira sp., Corallina sp.) and Determination of Its Effect by Biotreatment. University of Giresun, Graduate School of Natural and Applied Sciences, Department of Biology, Master dissertation, pp.34, Giresun.

Koç H. 2013. Production Processes of Organic Fertilizer From Some Marine Algae (Ulva sp., Cystoseira sp. and Corallina sp.) Collected Along Giresun Coastals and Determination of Their Plant Nutrient Elements. Graduate School of Natural and Applied Sciences, Department of Biology, Master dissertation, pp.33, Giresun.

Kurama H, Ataşlar E, Potoğlu İ, Savaroğlu F, Tokur S. 1999. The Effects of Zeolit on Seed Germination and Plant Growth of Triticum Sativum and Cucumis Sativus. Ekoloji, 8(32): 2127. 
Lai WA, Rekha PD, Arun AB, Young CC. 2008. Effect of Mineral Fertilizer, Pig Manure, and Azospirillum rugosum on Growth and Nutrient Contents of Lactuca sativa L. Biology and fertility of soils, 45 (2): 155-164. DOI: 10.1007/s00374008-0313-3

Lakshmi S, Sundaramoorthy P. 2010. Response of Vigna unguiculata on Liquid Seaweed Fertilizer. International Journal of Current Research, 2: 39-42.

Lazcano C, Revilla P, Malvar RA, Domínguez J. 2011. Yield and Fruit Quality of Four Sweet Corn Hybrids (Zea mays) Under Conventional and Integrated Fertilization with Vermicompost. J of the Sci of Food and Agri, 91(7): 12441253. DOI: $10.1002 /$ jsfa.4306

Rathore SS, Chaudhary DR, Borincha GN, Ghosh A, Bhatt BP, Zodape ST, Patolia JS. 2009. Effect of Seaweed Extract on the Growth, Yield and Nutrient Uptake of Soybean (Glycine max) Under Rainfed Conditions. South African Journal of Botany, 75, 351-355. DOI: 10.1016/j.sajb.2008.10.009

Raverkar KP, Pareek N, Chandra R, Chauhan S, Zodape ST, Ghosh A. 2016. Impact of Foliar Application of Seaweed Saps on Yield, Nodulation and Nutritional Quality in Green Gram (Vigna radiata L). Legume Res, 39(2): 315- 318. DOI: 10.18805/lr.v39i2.9535

Rebours C, Friis Pedersen S, Øvsthus I, Roleda M. 2014 Seaweed-a Resource for Organic Farming. Bioforsk Fokus, 9 (2): 107.

Sathya B, Indu H, Seenivasan R, Geetha S. 2010. Influence of Seaweed Liquid Fertilizer on the Growth and Biochemical Composition of Legume Crop, Cajanus cajan (L.) Mill sp. Journal of Phytology, 2 (5): 50-63.

Sivasankari S, Venkatesalu V, Anantharaj M, Chandrasekaran, M. 2006. Effect of Seaweed Extracts on the Growth and Biochemical Constituents of Vigna sinensis. Bioresource Technology, 97 (14): 1745-1751. DOI: 10.1016/j.biortech. 2005.06.016
Sönmez S, Kaplan M, Sönmez NK, Kaya H. 2006. Effects of High Level Copper Applications to Soil on $\mathrm{pH}$ and Nutrient Element Contents of Soil. Med Agric Sci, 19 (1): 151-158.

Tepe Y, Akyurt I, Ciminli C, Mutlu E, Caliskan M. 2004. Protective Effect of Clinoptilolite on Lead Toxicity in Common Carp Cyprinus carpio. Fresenius Environmental Bulletin, 13 (7): 639-642.

Türkmen A, Kütük Y. 2017. Effects of Chemical Fertilizer, Algea Compost and Zeolite on Green Bean Yield. Turkish J of AgrFood Sci and Tech, 5(3): 289-293. DOI: 10.24925 /turjaf.v5i3.289-293.977.

Wickham A, Davis JG. 2015. Effect of Liquid Organic Fertilizers and Seaweed Extract on Daucus carota var. sativus Growth Characteristics. Western Nutrient Management Conference, 11: 194-199.

Yildiz N. 2001. The Methods of Determination of Some Soil Pollutant Heavy Metals. Atatürk Üniversitesi Ziraat Fakültesi Dergisi. 32 (2): 207-213.

Zahid PB. 1999. Preparation of Organic Fertilizer from Seaweed and Its Effect on the Growth of Some Vegetable and Ornamental Plants. Pak J of Biol Sci, 2 (4): 1274-1277.

Zaller JG. 2006. Foliar Spraying of Vermicornpost Extracts: Effects on Fruit Quality and Indications of Late-Blight Suppression of Field-Grown Tomatoes. Biol Agric \& Hortic, 24 (2): 165-180. DOI: 10.1080/01448765.2006.9755017

Zodape ST. 2001. Seaweeds as a Biofertilizer. J of Sci \& Industr Res. 60: 378-382.

Zodape ST, Kawarkhe VJ, Patolia JS, Warade AD. 2008. Effect of Liquid Seaweed Fertilizer on Yield and Quality of Okra (Abelmoschus esculentus L.). Journal of Scientific \& Industrial Research, 67: 1115-1117 